\title{
Bill C-31: \\ Limited Access to \\ Refugee Determination and Protection
}

\author{
Michael Bossin
}

\begin{abstract}
This article deals with the effect of the proposed Immigration and Refugee Protection Act (Bill C-31) on access to Canada's refugee determination system and its pre-removal risk-assessment procedures. The author examines public statements about government plans for increased overseas interdiction of refugee claimants, provisions that expand the definition of persons ineligible to have their claims heard by the Immigration and Refugee Board (particularly those concerning "serious criminality"), and the proposed new system for pre-removal risk assessment. His conclusion is that, should these proposals come into effect, fewer people will have access to refugee and other protection in Canada.
\end{abstract}

\section{Résumé}

Cet article se penche sur les conséquences qu'aurait la proposition de loi concernant l'immigration et l'asile (projet de loi C-31) sur l'accès au système de détermination du statut de réfugié au Canada et les procédures d'évaluation des risques avant le renvoi qu'elle contient. L'auteur examine les déclarations publiques concernant les plans du gouvernement pour accroître le nombre d'interdictions de demandeurs d'asile à l'étranger, pour étendre la définition de personnes dont les demandes sont considérées irrecevables pour être entendues par la Commission de l'immigration et du statut de réfugié - tout particulièrement celle concernant « la criminalité grave» - et le système préconisé d'évaluation des risques avant le renvoi. Sa conclusion est que si ces propositions sont adoptées, moins de personnes auront accès à l'asile au Canada.
Introduction
he Immigration and Refugee Protection Act (Bill
C-31), introduced in April 2000, includes some
measures that will improve upon Canada's system of refugee determination. These include an expanded definition of those deserving of protection and an appeal on the merits of rejected claims. That being said, the most specialized and fair procedure is of little value if one does not have access to its processes. And make no mistake, limiting access to refugee protection in Canada is precisely the intent of the Canadian legislators who introduced Bill c-31 into Parliament. Under its provisions, fewer people will be able to benefit from Canada's asylum procedures. This is a consequence of increased overseas interdiction of those seeking to come to Canada to make refugee claims, an expanded definition of who is ineligible to have his or her claim heard by the Immigration and Refugee Board (IRB), and limited access to a new pre-removal risk assessment.

\section{Interdiction}

The provisions of Bill c-31 do not mention increased overseas interdiction, but the intent of the government is clear from media releases and statements made around the time of the Bill's introduction. In a press release, the Minister of Citizenship and Immigration declares that one goal of the new legislation is to "close the backdoor to those who would abuse the system." ${ }^{1}$ As a way of achieving that goal, the Minister declares that she has secured funding for "steppedup overseas interdiction." ${ }^{2}$

The same press material notes that increased overseas interdiction means " $[\mathrm{m}]$ ore immigration control officers stationed at our offices abroad to direct genuine refugees to appropriate missions or international organizations 
while preventing undocumented persons from seeking irregular channels of migration to Canada."' 3 The stated purpose of this action is "to discourage those not in need of protection from coming to Canada through irregular means."

The phrase "at our offices" abroad is, I believe, misleading. It suggests a place of meeting and discussion. In fact, most interdiction by Canadian officials occurs at overseas airports, where the documents of persons boarding Canadian-bound planes are checked. "At our offices" suggests an investigatory, even conciliatory, approach. The reality of "at the airport" reveals a much more enforcementoriented process.

The enforcement mentality is revealed as well in language used by the government to describe its interdiction policy. For example, non-genuine refugee claimants are described as "undocumented persons" and those seeking to come to Canada through "irregular means." As Amnesty International observes in its brief on Bill c-31,

Sometimes the only way that genuine refugees can escape persecution in their own countries and seek asylum abroad is through "irregular channels" and by means of false documentation. The language in the [press material], however, suggests that "undocumented persons" "seeking irregular channels of migration to Canada" are not "genuine refugees." In our experience, in many cases, nothing could be further from the truth. It is this apparent misconception of what constitutes a "genuine refugee" which raises our concern about the welfare and safety of those interdicted abroad. ${ }^{5}$

The government promises that "genuine refugees" shall be directed to "appropriate missions or international organizations." That, however, should not be confused with actually offering protection to those refugees or even ensuring that they have access to a fair determination. Besides, the proposal is premised on a false assumption-that one can easily distinguish a "genuine refugee" from one who is not genuine. As is evident to anyone who has ever been involved in a refugee hearing, that determination is, as a rule, not simple at all. It is far more complicated than merely confirming the validity of one's passport. Moreover, "immigration control officers," whose very title reveals their primary purpose, are neither suited nor trained to determine who is a "genuine refugee."

Were the Canadian government serious about protecting bona fide refugees, it would cease overseas interdiction. As the UNHCR notes, "the most effective way to ensure the integrity of asylum systems is not to erect barriers but rather, to process applications fairly and expeditiously [in the country of asylum]."' That involves "consistency in de- cision-making and the timely removal of rejected asylumseekers."'

At the very least, Canadian officials abroad should be satisfied that persons wishing to claim refugee status in Canada have access to an authority in another country before which they can exercise their right to seek asylum. That country must be a signatory to the 1951 Convention and be recognized as one that upholds its obligations under the Convention, in policy and practice. If such a referral is not possible, asylum-seekers should be allowed to continue their voyage to Canada. ${ }^{8}$

\section{Ineligibility}

\section{Restricted Access to the Refugee Board under the Current Legislation}

Since 1989, there has been an eligibility screening for all refugee claimants in Canada. That is, not all persons claiming to be refugees are allowed to have their claims heard by the Convention Refugee Determination Division (CRDD) of the IRв. Under the Immigration Act, determinations of eligibility are made by immigration officers. ${ }^{9}$ Persons not eligible to have their claims referred to the CRDD include:

- those who have been recognized as Convention refugees by another country, to which they can be returned ${ }^{10}$

- those previously determined not to be Convention refugees, or to have abandoned their claim, or determined not to be eligible to make a claim ${ }^{11}$

- those determined to be Convention refugees, under either the Immigration Act or the regulations ${ }^{12}$

- those determined by an adjudicator to have committed or been convicted of a serious crime, either in Canada or abroad, and who, in the Minister's opinion, constitutes a danger to the public ${ }^{13}$

- those determined by an adjudicator to be inadmissible for reasons of security, involvement with organized crime, war crimes or crimes against humanity, or for holding a senior position in a government complicit in human rights violations and whose claims, in the opinion of the Minister, it would be contrary to the public interest to have heard in Canada.

Under current legislation, those previously determined not to be Convention refugees can overcome this obstacle to eligibility by remaining out of the country for ninety days. After that period, failed refugee claimants returning to Canada will again have access to the CRDD for a determination of their claims. ${ }^{14}$

On a number of occasions, the legislative scheme of limiting access to the CRDD has been challenged for being in 
violation of the Canadian Charter of Rights and Freedoms, particularly of sections 7 and 15 (1). ${ }^{.5}$ In every case, the Federal Court has upheld the constitutionality of the eligibility provisions. ${ }^{16}$

Notwithstanding the Canadian jurisprudence, it is doubtful that the drafters of the 1951 Refugee Convention envisaged a system in which some asylum seekers would be unable to present their claims before the decisionmaking authority. Certainly, no article of the 1951 Convention specifically bars applicants from access to a refugee determination process. Under the Convention, persons may be excluded from refugee protection or may cease to be Convention refugees, but these exclusionary and cessation clauses do not envisage the absence of a refugee determination at all. By definition, cessation is an act that occurs after someone first has been determined to be a Convention refugee. As for excluding undeserving claimants from refugee protection, this too comes after an initial finding of inclusion. Notes the United Nations High Commissioner for Refugees' Handbook on Procedures and Criteria for Determining Refugee Status,

The inclusion clauses define the criteria that a person must satisfy in order to be a refugee. They form the positive basis upon which the determination of refugee status is made. The ... exclusion clauses ... enumerate the circumstances in which a person is excluded from the application of the 1951 Convention although meeting the positive criteria of the inclusion clauses (emphasis added). ${ }^{17}$

The UNHCR has long been of the view that "automatic bars to consideration of asylum claims are not in conformity with the 1951 Convention." ${ }^{18}$ Decisions on entitlement to refugee protection are often complex and challenging, and should be made by the authority with expertise and training in refugee law and status determination. In its submission to the House of Commons Standing Committee on Citizenship and Immigration, the UNHCR stated that the right under Article 14 of the Universal Declaration of Human Rights to seek and enjoy asylum from persecution "can only be exercised if the asylum-seeker has the opportunity to have his or her claim heard by an authority competent to do so. Asylum-seekers therefore must have access both to the territory of countries where persecution can be sought, and to the asylum procedures in those countries." ${ }^{19}$

Canada was also criticized for limiting access to its refugee determination process by the Inter-American Commission on Human Rights, in a report issued in February 2000. ${ }^{20}$ Basing its analysis on articles of the American Declaration of the Rights and Duties of Man, the Commission, although acknowledging that some claimants may be ineligible to have their claim determined, were concerned that eligibility screenings are conducted by immigration officers and not the Board. In its report, the Commission stated,

The right to seek asylum necessarily requires that asylum seekers have the opportunity to effectively state their claim before a fully competent decision-maker. While applicable international law leaves the decision as to which procedural means are necessary to accomplish this to the national authorities, the Commission shares the view of the UNHCR that eligibility determinations are best made by those tasked with interpreting and applying refugee law and policy. ${ }^{21}$

As we shall see, the views of the UNHCR and InterAmerican Commission on Human Rights are not reflected in the draft legislation, Bill c-31. In fact, access to refugee determination-indeed, to refugee protection-is even more limited under the proposed new law.

\section{Reforms under Bill c-31}

In Bill c-31, the proposed Immigration and Protection Act, some of the terminology on refugee claims has changed. The Convention Refugee Determination Division, for example, becomes the Refugee Protection Division (RPD) of the Immigration and Refugee Board..$^{22}$ In addition to determining people to be Convention refugees, the Division also has the power to declare applicants to be persons "in need of protection." The latter, with a number of exceptions, include those likely to face torture or cruel and unusual treatment or punishment, if removed from Canada. The system of screening refugee claimants for eligibility to have their claims heard by the Board, however, remains in place in the proposed legislation. In fact, the grounds for prohibiting access to the Board have been expanded.

Pursuant to section 95 (1) of the Bill, the following persons are ineligible to have their refugee claims referred to the RPD:

- those previously granted or refused refugee protection under the $\mathrm{Act}^{23}$

- those previously determined to be ineligible to have their claim referred to the PRD, or whose claims have been withdrawn or abandoned ${ }^{24}$

- those recognized as Convention refugees by a country other than Canada, to which they can be returned ${ }^{25}$

- those determined to be inadmissible on the grounds of security, violating human rights, serious criminality, or organized criminality ${ }^{26}$

- those who came directly to Canada from a country prescribed by Cabinet as being "safe," other than their own country of nationality or former habitual residence ${ }^{27}$ 
It is not my intention to comment on all of these provisions-only those where the most significant changes to the existing legislation have been made. In my view, these also happen to be the amendments likely to have the greatest impact in numerical terms: the sections dealing with serious criminality and previously rejected claims.

\section{Serious Criminality}

Under the current legislation, claimants must have been convicted of a "serious offence," ${ }^{28}$ and the Minister must be of the opinion that they constitute a "danger to the public" before they can be found ineligible to have their claims referred to the CRDD. ${ }^{29}$ In the proposed Immigration and Refugee Protection Act, the Ministerial opinion is not needed for a finding of ineligibility. The "serious offence" alone constitutes grounds for not referring a claim to be heard by the RPD..$^{30}$

The current practice, of having the Minister label certain refugee claimants a "danger to the public," has been subject to criticism on several fronts. On the government side, the determinations can be difficult and time-consuming. From the perspective of refugee advocates, the exercise of the Minister's discretion has been criticized primarily because, as the Canadian Bar Association has observed, "many, if not most, of those labelled public dangers were not public dangers in the objective sense of likelihood to reoffend." ${ }^{11}$ According to the свA, "The public danger label, rather than a true determination of public danger, is a form of venting anger against foreigners for past crimes. It is a modern form of forfeiture." 32

Whatever its shortcomings, there is implicit in the ministerial discretion on public danger the acknowledgment that not all persons convicted of a serious criminal offence are undeserving of a determination before the Refugee Board or, indeed, of refugee protection. For example, in her determinations of public danger, the Minister may consider such factors as the actual sentence imposed by the court, the age of the offender, whether this was a first offence, indicators of rehabilitation, and change in personal circumstances since the commission of the crime. None of these considerations can be taken into account under the proposed regime. Instead, there is an inflexible and arbitrary standard, one that is overly simplistic and, frankly, insensitive to the complexities that often arise in such cases.

One such complexity involves offences or criminal charges that are politically motivated. Under the 1951 Convention, only those persons who have committed "serious non-political" crimes are excluded from refugee protection..$^{33}$ A distinction is made between common criminals escap- ing legitimate prosecution and those whose actions were politically motivated, leading to a flight from persecution. "Serious criminality," as defined in Bill c-31, makes no such distinction. Political and non-political crimes are treated alike.

In fact, in Bill c-31 there is no provision for taking into account the political context in which crimes abroad were "committed," when determining ineligibility by reason of "serious criminality." This is problematic, since, in many countries the criminal justice system is used to suppress dissidents. It has been said that were Nelson Mandela a refugee claimant under the Immigration and Refugee Protection Act, he would be ineligible to have his claim heard by the Refugee Board. A more recent example of the type of person who would be detrimentally affected by the new legislation is James Torh, one of Liberia's most well-known and outspoken human rights defenders. Mr. Torh was arrested in December 1999 for criticizing the Liberian government and his president, while speaking to a group of secondary-school students. He was arrested, stripped naked, beaten, kicked, and charged with sedition. In the eyes of the international community, there is no doubt that the charges against James Torh are politically motivated. In Canada, sedition carries a sentence of up to fourteen years' imprisonment. If convicted in Liberia, where a fair trial is highly unlikely, James Torh would be ineligible to make a refugee claim in Canada. ${ }^{34}$

In the Immigration and Refugee Protection Act, there is an acknowledgment that persons found ineligible due to serious criminality may still be at risk if returned to their country of origin and, as a consequence, in need of protection. Under the Act, those found ineligible for such reason are referred to the Pre-Removal Risk Assessment (PRRA). ${ }^{35}$ The assessment includes a weighing of the potential risk to the individual if returned to his or her country of origin, and the risk to the Canadian public or the security of Canada should the person not be returned. ${ }^{36}$ Should the risk to the claimant outweigh the risk to the Canadian public, then his or her removal is stayed, subject to further review if circumstances change. ${ }^{37}$

In terms of protection, it is doubtful that referring "serious criminals" to the PRRA will be as effective as referring their claims to the RPD. Under the Immigration and Refugee Protection Act, the definition of risk applied by the RPD and the PRRA is the same. ${ }^{38}$ The only difference in the assessment would be that the former tribunal is far better trained and equipped to identify persons in need of protection. Moreover, with respect to the interests of the Canadian public, it is hard to see the advantages of the proposed system for dealing with claims of "serious criminals." 
In regard to protecting the public from dangerous criminals, there already are provisions for detaining any asylumseeker who poses a danger to the public. ${ }^{39}$ Moreover, claimants who have committed serious non-political crimes are excluded from refugee protection in any event. ${ }^{40}$ Finally, persons who have committed serious offences in Canada and are a danger to the public can still be removed from Canada, even if in need of protection. Such removals are consistent with Article 33 (2) of the 1951 Convention and are provided for both in the current legislation ${ }^{41}$ and under Bill c-31, where the danger to the public outweighs the risk to the person concerned. ${ }^{42}$ What, then, should be done with cases involving "serious criminality"? Clearly, some discretion needs to be exercised, in balancing the individual's need for protection against the public interest, including danger to the public. The pertinent questions are, Who is best suited to exercise that discretion? And at which stage of the proceedings should the discretion be exercised? One proposal has been to retain a pre-screening of claims, with the "danger to the public" criterion being determined by an adjudicator, instead of the Minister. ${ }^{43}$ Although this would result in more independent decision making, it would continue to be a time-consuming and potentially costly exercise.

A better solution, in my view, is simply to refer all refugee claims to the RPD. ${ }^{44}$ Where the eligibility criteria are met, a hearing on the merits can follow immediately thereafter. This approach would be both expedient and economical. Moreover, as indicated above, the Refugee Board is best suited to make determinations on the need for protection. The practice of denying some people access to refugee determination through a pre-screening mechanism only serves to increase the likelihood that genuine refugees will be removed from Canada, thereby violating Canada's obligations under Article 33 of the 1951 Convention. As the CCR states in its submissions on Bill C-31, "In order to comply with this obligation, Canada must, before removal, be sure that a person being removed is not a refugee. The refugee determination system [meaning consideration of a claim by the specialized, expert tribunal] exists to identify who is a Convention refugee and who is not." 45

\section{Claimants Previously Refused}

At first glance, the provision in Bill C-31 for claimants previously refused refugee protection ${ }^{46}$ appears identical to that found in the current legislation. ${ }^{47}$ It is very similar. The difference is found in another section of the Bill, dealing with how soon a rejected refugee claimant can return to Canada and initiate a subsequent claim. As mentioned above, un- der the Immigration Act, a period of ninety days outside the country will overcome the prohibition based on a previous refusal. Under Bill c-31, persons whose claims are rejected forever lose their right to have a refugee claim heard by the Immigration and Refugee Board again. ${ }^{47}$ Rejected claimants who, having spent at least one year outside Canada, return to seek asylum, are referred not to the RPD, but to the PRRA instead. ${ }^{49}$

The rationale for the "ninety-day rule" under the current Act is a recognition that circumstances may changeeither in a claimant's country of origin, or in his or her life, or both. Just because one's refugee claim is rejected at one point does not mean that he or she will never meet the definition of Convention refugee, or deserve protection, in the future.

The circumstances that lead to a need for protection, of course, can arise at any time. Under Bill c-31, however, only those failed refugee claimants who have been outside of Canada for one year or more are eligible for PRRA. No mechanism exists to provide protection, let alone a risk assessment, for those who return to Canada seeking asylum within the one-year period. Clearly, the failure to provide any assessment of risk for such individuals puts into question Canada's adherence to its obligations both under section 7 of the Charter and Article 33 of the 1951 Convention. ${ }^{50}$

As mentioned above, in terms of identifying persons in need of protection, it is unlikely that a review under PRRA will be as effective as a determination by the PRD. The draft legislation does not mention who conducts the former or how it is done. Most likely, it will be a paper review carried out by immigration officers, similar to the Post Claim Determination Officers who consider applications for membership in the Post Determination Refugee Claimants in Canada class (PDRCC) under the current legislation. However qualified these officers may be, they are not members of a specialized tribunal dealing with protection issues. Nor can it be said that a paper review is of the same quality as a hearing. Moreover, where a claim for refugee protection has previously been refused, "the only new evidence that may be presented [for PRRA] is new evidence that arose after, or that was not reasonably available at the time of, the rejection." ${ }^{11}$ The meaning of the latter phrase is not clear. Does it include evidence that was available at the time of the first hearing, but was not presented due to incompetent counsel or because the claimant was unrepresented? What about evidence not forthcoming because the claimant was suffering from undiagnosed trauma or domestic abuse? Ideally, any evidence relevant to the issue of risk 
ought to be considered in a risk assessment. Unfortunately, the wording of the proposed Immigration and Refugee Protection Act is not open to such a liberal interpretation.

Presumably, the government's intention in changing the "ninety-day rule" into a "one-year rule" was to deter abusive, repeat claims from occurring. However, as the Canadian Bar Association has proposed, "[a]buse through 'revolving claims' can be dealt with expeditiously through the doctrine of res judicata, which prevents re-litigation of the same issues on the same evidence." ${ }^{52}$ Moreover, it is likely that the number of repeat refugee claims will be reduced under the new legislation because of an appeal on the merits for failed claimants. Presumably, many repeat claims were the consequence of the limited appeal that is available to rejected refugee claimants under the Immigration Act-a judicial review, with leave, based on error of law, excess or lack of jurisdiction, a principle of natural justice, or procedural fairness. ${ }^{53}$ Many failed claimants simply returned to Canada after ninety days and tried again, hoping for a more experienced or sympathetic CRDD panel, better counsel, and/or better evidence. With an appeal on the merits, the incentive to leave Canada and institute a subsequent claim is greatly diminished.

\section{Claims Abandoned or Withdrawn}

Those persons whose refugee claims were previously rejected are not the only ones with restricted access to the Pre-Removal Risk Assessment. Another category of claimants with limited access to the PRRA are those whose claims have been abandoned or withdrawn. Such persons are not eligible for a risk assessment until one year after their departure from Canada. ${ }^{54}$

There are many reasons that refugee claims are abandoned or withdrawn. In the case of the former, it may be that the individual leaves Canada, or realizes that he or she does not fit the definition of a Convention refugee. In such cases, the "one-year rule" may appear to be appropriate. Other factors, however, may also account for the abandonment of a claim. The claimant may suffer from mental illness and not have understood the notices sent by the Board. He or she may have received wrong advice or information about how to pursue the claim. In some cases, the claimant may be the victim of domestic abuse and not realize that Canada is one of the few countries in the world that recognizes it a ground for refugee protection. Alternatively, the trauma suffered by the abuse, or past incidents of torture or mistreatment, may have impeded the individual from proceeding with the claim. In my view, should the claimant be able to present reasonable grounds for abandoning the refugee claim, he or she should be entitled to a preremoval risk assessment.

The most common reason for withdrawing a claim is that another means of obtaining status in Canada is available to the claimant, usually through sponsorship. Withdrawing a claim in these circumstances does not necessarily mean that the need for protection disappears. In this example, should the sponsorship break down, a risk assessment before removal would be appropriate. Again, as in the cases of previously rejected claim and abandonment, the provisions of the proposed new legislation are too inflexible. That inflexibility could lead to serious human rights violations being suffered by persons excluded from a preremoval risk assessment.

\section{Conclusion}

There is a tendency for Canadian politicians to appear tough as well as fair in their approach to immigration reform. Ideally, measures meant to curb abuse of the immigration and refugee system should not diminish our country's effectiveness in dealing humanely with those who seek asylum in Canada. In my view, the restrictions in Bill c-31 on access to the refugee determination process, and to refugee protection in general, do just that. The Bill, though dying on the order table of the last Parliament, is likely to re-appear on the new government's agenda. One would hope that in its second incarnation, some of its original toughness will be replaced by a somewhat larger dose of humanity.

\section{Notes}

1. Citizenship and Immigration Canada, "Caplan Tables New Immigration and Refugee Protection Act," news release (Ottawa: CIC, April 6, 2000) at 1.

2. Ibid., at 2.

3. Ibid., at 3 .

4. Ibid

5. Amnesty International, Amnesty International and Refugee Issues: A Submission to the Minister of Citizenship and Immigration on Bill C-31 (Ottawa: AI, June 2000) (hereinafter Amnesty International Brief), at 2.

6. United Nations High Commissioner for Refugees, "Comments on Bill C-31" (Ottawa: UNHCR, July 11, 2000) (hereinafter referred to as the UNHCR Brief), at paragraph 39.

7. Ibid.

8. This was a recommendation contained in the Amnesty International Brief, at 2.

9. Immigration Act, s. 45 (1) (a).

10. Ibid., s. 46.01 (1) (a).

11. Ibid., s. 46.01 (1) (c).

12. Ibid., s. 46.01 (1) (d). 
13. Immigration Act, s. 46.01 (1) (e) (i) (iii) (iv).

14. Ibid., s. 46.01 (5).

15. Section 7 of the Charter states, "Everyone has the right to life, liberty and security of the person and the right not to be deprived thereof except in accordance with the principles of fundamental justice." Section 15 (1) states, "Every individual is equal before and under the law and has the right to the equal protection and equal benefit of the law without discrimination and, in particular, without discrimination based on race, national or ethnic origin, colour, religion, sex, age or mental or physical disability."

16. See, for example, Nguyen v. Canada (Minister of Employment and Immigration), [1993] 1 F.C. 696; 100 D.L.R. $\left(4^{\text {th }}\right) 151 ; 18 \mathrm{Imm}$. L.R. (2d) 165; 151 N.R. 69 (C.A.); McCallister v. Canada (Minister of Citizenship and Immigration) [1996] 2 F.C. 190; Gervasoni v. Canada (Minister of Citizenship and Immigration) [1996], 34 Imm. L.R. (2d) 80.

17. United Nations High Commissioner for Refugees, Handbook on Procedures for Determining Convention Refugee Status (Geneva: UNHCR, 1998) at paragraph 31.

18. UNHCR Brief, at paragraph 40.

19. Ibid., at paragraph 37 .

20. Inter-American Commission on Human Rights, Report on the Situation of Asylum Seekers within the Canadian Refugee Determination System, OEA/Ser.L/V/II.106, February 28, 2000.

21. Ibid., at paragraph 68.

22. Bill C-31, An Act Respecting Immigration to Canada and the Granting of Refugee Protection to Persons Who Are Displaced, Persecuted or in Danger, Second Session, Thirty-sixth Parliament, 48-49 Elizabeth II, 1999-200o, s. 148.

23. Ibid., (1) (a).

24. Ibid., (1) (b).

25. Ibid., (1) (c).

26. Ibid., (1) (d).

27. Ibid., (1) (e).

28. "Serious offence" means one for which the potential punishment is ten or more years of imprisonment. If the crime is committed, or if there has been a conviction outside Canada, one considers the potential sentence for the "equivalent" offence in this country.

29. Immigration Act, s. 46.01 (e) (i).

30. Bill c-31, s. 32 (2) (b); s. 95 (1) (d).

31. Canadian Bar Association, Citizenship and Immigration Law Section, Submission on Bill C-31 (Ottawa: СıBA, October 2000) (hereinafter referred to as the $C B A$ Brief) at 87.

32. Ibid., at 88 .

33. United Nations Convention relating to the Status of Refugees, Article 1 (F) (b).

34. The arrest, detention, and charge of sedition against James Torh are described in the 2000 Amnesty International Report, at 159.

35. Bill C-31, s. 107 (4).

36. Ibid.

37. Ibid., s. 107 (5), (6).

38. Ibid., section 89, 90 (2), 107 (1) and (2).

39. Ibid., s. 51 (1).

40. Ibid., s. 91.
41. Immigration Act, s. 53 (1).

42. Bill C-31, s. 107 (4).

43. See, for example, the Amnesty International Brief, at 4.

44. This proposal was made by the Canadian Council for Refugees, Comments on Bill C-31 (Montreal: CCR, July 4, 2000, (hereinafter CCR Brief) at 21, and the Canadian Bar Association, СвA Brief, at 92.

45. CCR Brief, 21.

46. Bill C-31, s. 95 (1) (a).

47. Immigration Act, s. 46.01 (1) (c).

48. The only exceptions would be those who are successful on appeal or judicial review and have their claims sent back for reconsideration.

49. Bill C-31, s. 107 (3) (a).

50. Article 33 of the 1951 Convention states, "No Contracting State shall expel or return a refugee in any manner whatsoever to the frontiers of territories where his life or freedom would be threatened on account of his race, religion, nationality, membership in a particular social group or political opinion."

51. Bill C-31, s. 107 (3) (b).

52. СвА Brief, at 95 .

53. Immigration Act, s. 82.1 (1); Federal Court Act, R.S.C. 1985, c. F-7, as amended, s. 18.1 (4).

54. Bill C-31, s.107 (3) (a).

Michael Bossin is a lawyer at Community Legal Services in Ottawa, specializing in immigration and refugee law. He teaches immigration law at the University of Ottawa Law School and is the president of the Canadian Section of Amnesty International (English-speaking branch). 